\title{
Integrating Sediment (dis)Connectivity into a Sediment Yield Model for Semi-Arid Catchments
}

\author{
Louise Lodenkemper $^{1,2, *}$, Kate Rowntree ${ }^{2}$, Denis Hughes ${ }^{3}$ and Andrew Slaughter ${ }^{3}$ \\ 1 Zutari (Pty) Ltd., Africa Water, Cape Town 1744, South Africa \\ 2 Geography Department, Rhodes University, Grahamstown 6140, South Africa; k.rowntree@ru.ac.za \\ 3 Institute of Water Resources, Rhodes University, Grahamstown 6140, South Africa; d.hughes@ru.ac.za (D.H.); \\ a.slaughter@ru.ac.za (A.S.) \\ * Correspondence: louise.lodenkemper@zutari.com; Tel.: +27-21-526-9400
}

\section{check for}

updates

Citation: Lodenkemper, L.; Rowntree, K.; Hughes, D.;

Slaughter, A. Integrating Sediment (dis)Connectivity into a Sediment Yield Model for Semi-Arid Catchments. Land 2021, 10, 1204. https: / / doi.org/10.3390/land 10111204

Academic Editors: Artemi Cerdà, Erick R. Bandala, Yang Yu and Jesús Rodrigo-Comino

Received: 8 August 2021

Accepted: 12 September 2021

Published: 7 November 2021

Publisher's Note: MDPI stays neutral with regard to jurisdictional claims in published maps and institutional affiliations.

Copyright: (c) 2021 by the authors. Licensee MDPI, Basel, Switzerland. This article is an open access article distributed under the terms and conditions of the Creative Commons Attribution (CC BY) license (https:/ / creativecommons.org/licenses/by/ $4.0 /)$.

\begin{abstract}
Soil erosion-associated sedimentation has become a significant global threat to sustainable land and water resources management. Semi-arid regions that characterise much of southern Africa are particularly at risk due to extreme hydrological regimes and sparse vegetative cover. This study aims to address the need for an erosion and sediment delivery model that successfully incorporates our conceptual understanding of sedimentation processes in semi-arid regions, particularly sediment storage and connectivity within a catchment. Priorities of the Semi-arid Sediment Yield Model (SASYM) were simplicity and practical applicability for land and water resource management while adhering to basic geomorphic and hydrological principles. SASYM was able to represent multiple sediment storages within a catchment to effectively represent a change in landscape connectivity over geomorphic timeframes. SASYM used the Pitman rainfall-runoff model disaggregated to a daily timescale, the Modified Universal Soil Loss Equation (MUSLE), incorporating probability function theory and a representation of sediment storages and connectors across a semi-distributed catchment. SASYM was applied to a catchment in the Karoo, South Africa. Although there were limited observed data, there was a historical dataset available for the catchment through dam sedimentation history. SASYM was able to effectively present this history and provide evidence for landscape connectivity change.
\end{abstract}

Keywords: semi-arid; sediment storage; connectivity; erosion model

\section{Introduction}

Although erosion is a natural landscape process, the evolutionary timescale is being modified by human impacts on land and water resources. Soil erosion and sedimentation is a global problem as the world's population grows and our resource requirements expand. This has serious environmental, economic and social consequences, including loss of productive land, sedimentation of reservoirs, reduction of water quality for human use and impacts on aquatic ecosystems [1-8]. These issues are particularly problematic in the semi-arid regions of developing countries, as many are vulnerable to reductions in soil productivity and water availability. Unfortunately, the physical characteristics of semi-arid areas, together with poor land management, have meant that the landscape is predestined to high erosion and sedimentation rates $[3,4,9]$. These characteristics linked to the negative impacts on soil productivity have meant that there has been a significant focus on land degradation by land managers. What is lacking is a tool which effectively quantifies sediment yield in these data-poor regions.

The ability to predict sediment yield is hampered by limited understanding of the drivers of erosion and the use of inappropriate prediction methods. Quantifying this process is problematic due to the difficulty in obtaining and verifying information on the complex suite of sediment sources, pathways, transport rates and delivery mechanisms [10]. The problem is compounded in data-scarce developing countries. Africa is consistently 
under-represented in global sediment yield compilations due to the limited number of sediment yield observations available [11].

It has long since been recognised that sediment yield at the catchment outlet does not necessarily reflect the gross soil erosion within a catchment due to depositional losses [12-15]. Meade [14] emphasised that sediment particles entrained by water erosion are more likely to spend a short amount of time being transported relative to that in storage. More attention therefore needs to be paid to the role of sediment stores in moderating catchment sediment yield.

Sediment yield models to date have not dealt effectively with the issue of scale as modelling approaches have either applied a sediment delivery ratio to erosion estimated from upscaled simplistic plot models (e.g., Soil and Water Assessment Tool (SWAT) [16]) or attempted to incorporate a full suite of catchment scale processes, creating unnecessary complexity (e.g., Agricultural Catchments Research Unit (ACRU) [17]). The major limitations in available models are either the lack of consideration of sediment deposition and storage within a catchment or the use of too many parameters, which are difficult to calibrate in data-poor regions.

The overall aim of the research presented here was therefore twofold: first, to provide a qualitative understanding of the sediment dynamics of semi-arid regions of South Africa and, second, to use this understanding to develop a quantitative erosion and sediment delivery model that provides a simple and practical tool for land and water resource managers. The model, called the Semi-arid Sediment Yield Model (SASYM), was tested by applying it to scenarios of historical landscape connectivity change in a catchment in the semi-arid Karoo of South Africa. Hypotheses proposed to explain a response to land use change were tested using SASYM.

\section{Sediment Processes in Semi-Arid Areas}

All landscapes adjust and evolve but what is important for sediment management is to explain the controls that drive process interactions, how they have changed or adjusted over time and to interpret what has triggered these changes [18]. Differing controls on landscape behaviour operate over variable spatial and temporal scales. These can be effectively represented through the traditional notion of scales of river structure, that is the source, transfer and sink concepts as defined by Schumm [19].

In the source zone, sediment comes primarily from the detachment of soil cover by the erosive agents of raindrop impact and runoff [20]. Once detached, soil particles are transported by flowing water and deposited, where low slope gradient or dense ground cover decrease velocity. In semi-arid areas the protective role of vegetation cover characteristic of humid climates [21] is restricted by low moisture availability. Often a pattern of bare and vegetated patches is formed, causing runoff to be highly discontinuous owing to nonuniform infiltration [22]. The relationship of vegetation cover and water availability is highlighted in "badland" areas where erosion is particularly rapid that reestablishment of vegetation cover is inhibited, further enhancing erosion through positive feedback [23]. Extremely high drainage densities in badlands are regarded as evidence of the dominance of overland flow [24].

Sediment conveyance in the transfer zone of semi-arid areas is characteristically "jerky" [25,26]. Irregular rainfall events and depressed water tables have meant that most dryland rivers are ephemeral, with channels flowing infrequently and for short periods [27]. This creates a hydrological "disconnect" through the tendency of dryland rivers to experience downstream decreases in flow volume, normally as a result of transmission losses from floodwater infiltrating into channel boundaries, overbank flooding and evaporative losses [28,29].

Diminished discharge due to transmission losses and a decline in slope results in a decrease in stream power and the deposition of excess sediment in storage zones, or sinks. These sinks may be temporary, persisting between significant storm events, or may act as long-term sediment stores in the form of floodplains, fans, floodouts or reservoir 
sediments. Sinks can be reworked and become sediment sources during high magnitude events or once the storage capacity is effectively filled. Gully erosion is a common process responsible for reworking long-term hillslope or valley floor sinks, while at the same time, increasing connectivity within the landscape [30-32].

Depending on the position of fluvial landforms and their sediment residence time, at any one time, parts of a catchment may be actively contributing sediment to the sediment cascade, considered to be analogous to being "switched on", others may be inactive and "switched off" [33]. In semi-arid systems, the pattern of source, transfer and sink zones, as well as the level of (dis)connectivity is more likely to reflect the last high magnitude, low frequency event that was able to "flush out" sediment through the system [19,34,35]. Sediment moves in infrequent bursts each time the valley floor channel is reactivated [26].

\section{Model Design Criteria}

The qualitative understanding of semi-arid regions was built into the design of the SASYM model through meeting four sets of criteria. First, SASYM was required to be applicable to semi-arid areas where flows are episodic and sediment travels through a disconnected sequence of stores. The episodic nature of flow means that, second, SASYM had to operate at short time steps in response to short lived storm events. Third, SASYM was designed to be compatible with a hydrological model familiar to South African water engineers, and fourth, the model structure should avoid unnecessary complexity that requires calibration of many parameters.

Bryson [36] provides full details of the SASYM development. Here, we explain how SASYM is structured to take account of key processes in semi-arid catchments, including connectivity in the sediment cascade in terms of source, transfer and sink process. We demonstrate its successful application to a South African catchment that provided a rare opportunity for model calibration owing to observations based on palaeo-environmental reconstruction of dam sedimentation rates spanning over 100 years [37].

\section{Conceptual Basis of the Model}

In accordance with the important factors related to sediment dynamics in semi-arid catchments, SASYM is separated into surface flow, erosion and an estimation of sediment storage and delivery. A conceptual framework was translated into a set of model equations governed by a set of parameters. The equations through which erosion and sediment transport are estimated are detailed in Appendix A for erosion estimation and Appendix B for sediment transport estimation. These parameters and outputs from a rainfall-runoff model are the inputs to SASYM. The model outputs are the total mass of daily erosion and total mass of sediment delivery at various points within the system.

\subsection{Runoff Modelling and Catchment Zones}

The surface flow estimation is determined through the use of the Pitman rainfallrunoff model [38] to allow for an effective integration of a widely used hydrological model that many South African water resource managers are already familiar with. Runoff events in semi-arid areas are typically short lived, often lasting for less than a day. Sub daily rainfall is seldom available to modellers; pragmatically SASYM needs to run on a daily time step if processes are to be effectively simulated. Inputs to the Pitman model are daily rainfall but as the conventional model runs on a monthly time step the generated flows must be disaggregated to daily using a monthly-daily flow disaggregation method [39].

The catchment is portioned into zones through a conceptualisation of gradient, although it is acknowledged that, in reality, more complex factors are involved. These zones are divided into steeply sloping headwater areas around the catchment boundary $(\mathrm{H})$, less steep mid-slope areas (M) and the lower flatter valley bottom areas (L). Model parameters are required to specify the proportion of the total catchment area occupied by these three zones. The combined catchment zones (i.e., H, M, and L) can be considered as the "source" zone for erosion in the catchment. 


\subsection{Estimating Erosion}

Many advanced erosion and sediment yield models are based on modifications of the Universal Soil Loss Equation (USLE) [40]; the accuracy of sediment yield estimates is compromised by the limited consideration of deposition processes or gully and stream bank erosion [41]. Despite these limitations, the USLE, Modified Universal Soil Loss Equation (MUSLE) [42] and Revised Universal Soil Loss Equation (RUSLE) [43] are several of the most widely applied erosion models in the world [41].

Consistent with many sediment yield models, the erosion module of the SASYM, applied to each source zone, was based on the MUSLE procedure. MUSLE [44] replaces the rainfall energy factor of the USLE with a runoff factor, which is claimed to be a better representation of the driver of erosion in semi-arid areas [45]. A review of the international application of MUSLE has been presented by Sadeghi et al. [46], who evaluated the applicable conditions and methods used to determine the MUSLE model variables in research. They concluded that application of the MUSLE model may provide reasonable results when applied under appropriate conditions similar to the original model (i.e., plot scale) or when the model factors are calibrated in accordance with the research context. Although this equation may not be considered mathematically sound on its own $[47,48]$, integrating it with a sediment transport model makes more sense.

In SASYM, sediment within each catchment zone is made available through the process of surface erosion, estimated for each time step as a function of hillslope surface runoff in accordance with the MUSLE [42] (Appendix A). Probability function theory is used to allow for the stochastic nature of erosion. This calculation is based on the estimation of factors for runoff (R) [44], topography (LS) [49], cover (C) [40], practice (P) [40] and soil erodibility $(\mathrm{K})[50]$ by randomly sampling uniform probability distributions of the factors in each runoff zone. Estimation of the surface flow for the three catchment zones depends on calculation of the proportions of the catchment in each zone, daily surface runoff depth ([51] baseflow separation method), a storm duration-volume relationship scaling factor and power and constant parameters.

\subsection{Sediment Routing}

Fryirs [52] suggests that the best approach to deal with the issue of scale in sediment delivery modelling is to focus on the sediment cascade and analyse the strength of linkages within a catchment. Sediment flux may primarily be reflected in the reorganisation of temporary sediment stores within the catchment rather than as a direct change in the catchment sediment yield [33,53]. A lumped model is not able to reflect this behaviour; therefore, a semi-distributed modelling approach is more appropriate.

Sediment routing considers the movement of sediment from the "source" zone into "transfer" or "sink" zones. In SASYM, the available sediment produced by the erosion sub-model either enters storage within the catchment or is removed from the catchment at its outlet as depicted in Figure 1. The driver of this process is runoff. Each catchment zone $(\mathrm{H}, \mathrm{M}$, and $\mathrm{L})$ is assumed to have two storage components, one representing hillslopes and one representing channel features (gullies or channels). The sediment availability calculated from the erosion model for each runoff zone (SAH, SAM, and SAL) is assumed first to be added to the slope storage within the catchment zone (SH, SM, and SL). The slope storage can then contribute to the channel storage within that zone according to an assigned proportion (CpropH, CpropM, and CpropL), as well as to slope storage in a lower zone (SH leading to SM and SM leading to SL). The channel storage in each zone can also contribute to the channel storage in a lower zone. The main channel storage receives sediment from the slope (SL) and channel storage (CpropL) of the low catchment zone. Any outputs from the main channel storage represent the total catchment sediment delivery. Over time, changes to the strength of connectivity between landscape units may be represented through incorporation of a "switch". Adjustments of the degree of connectivity will be considered as an adjustment to the strength of connectivity between 
the "source" and "sink" zone via manual adjustment of the "transfer" zone. This increases the proportion of sediment moving between sediment stores.
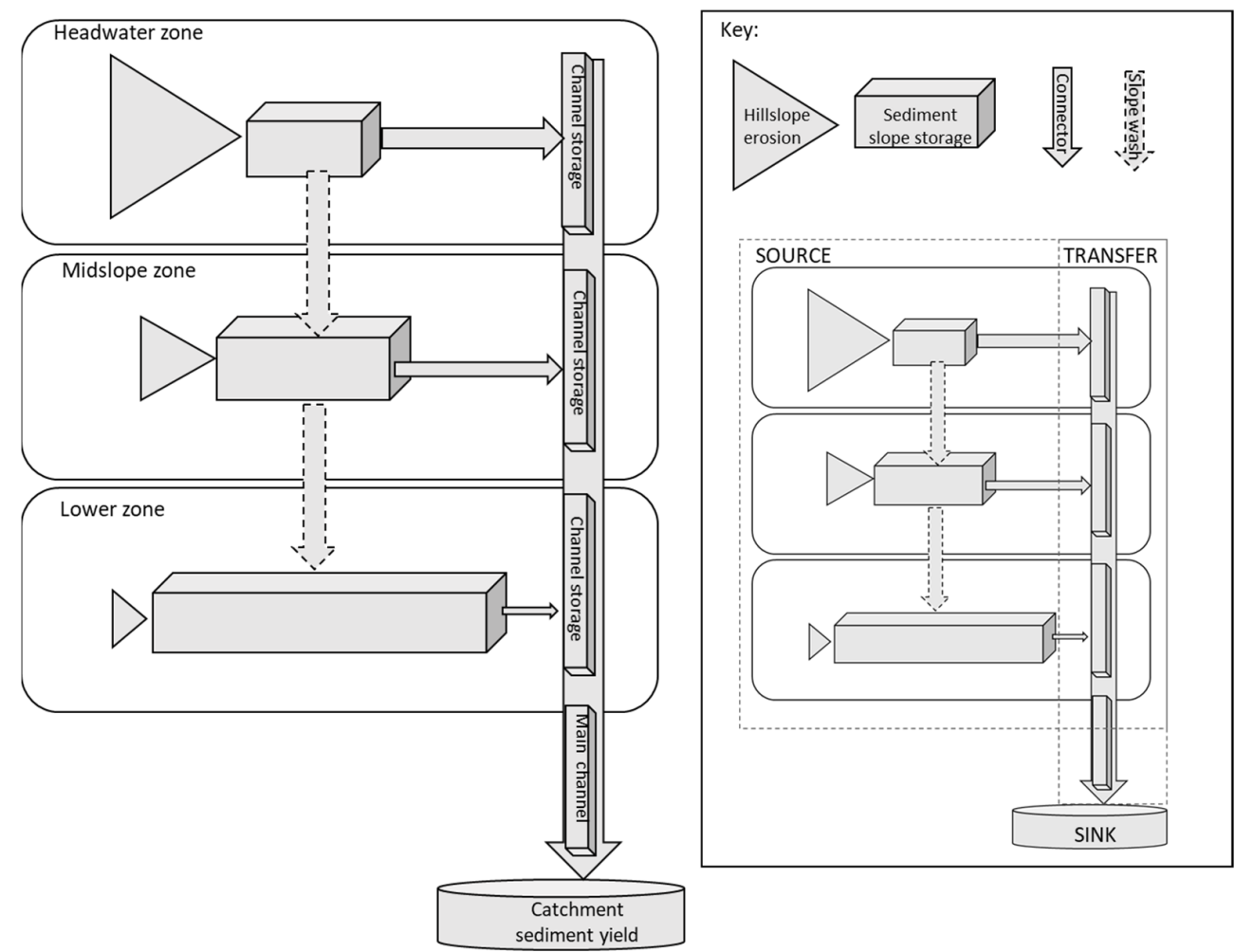

Figure 1. A conceptualisation of the erosion and sediment yield model, indicating the two types of storage in each catchment zone and the movement of sediment between zones along a longitudinal profile.

The sediment delivery during any day of the time series is determined by: (1) the relative amount of sediment in storage; (2) the relative size of any day's runoff event compared to the maximum size of a runoff event expected in the specific catchment; and (3) a parameter representing a flow threshold for sediment movement.

\subsection{Representing (dis)Connectivity}

A change in landscape connectivity is represented through changing the proportion of sediment stored in the "transfer zone" or the gully connectors (Figure 2). A change in connectivity within the time series can be manually adjusted by running the model twice with different connectivity proportions and then combining the outputs. 


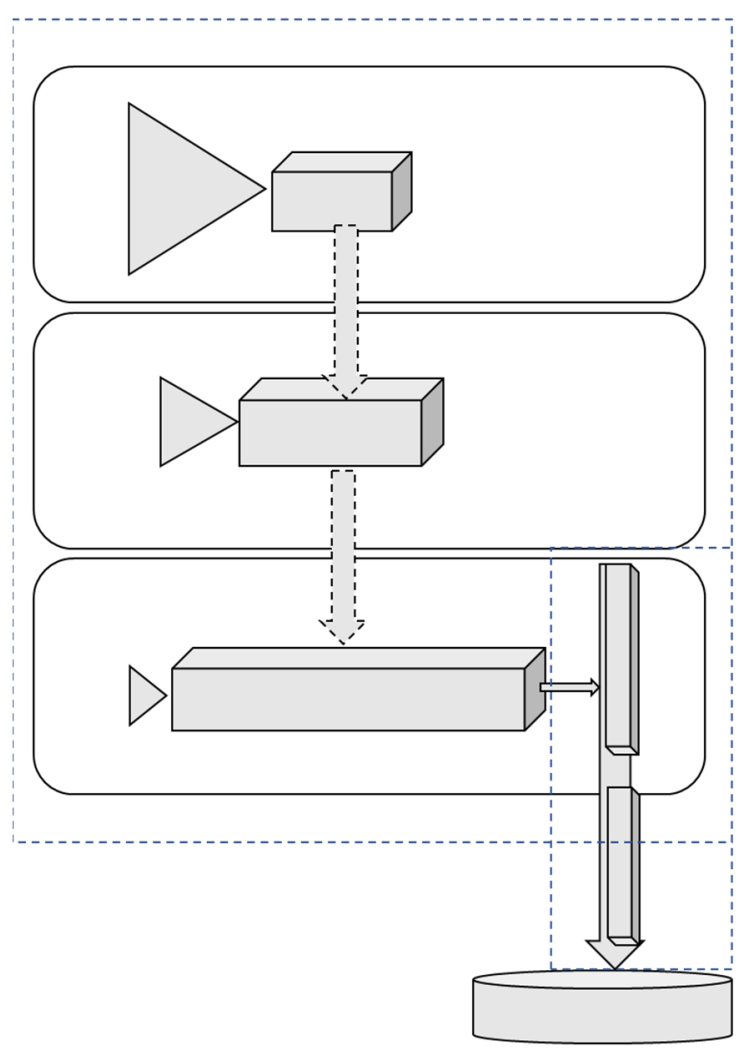

(a)

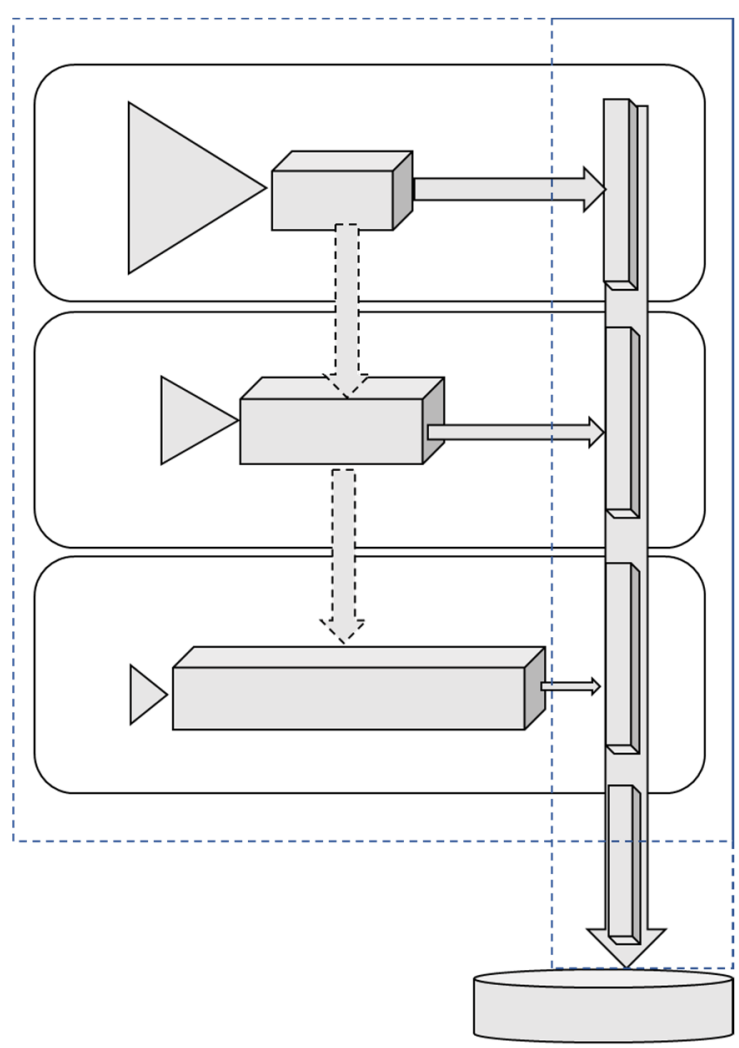

(b)

Figure 2. A conceptualisation of the "switch" in connectivity in a catchment. (a) presents a (dis)connected catchment and (b) presents a connected catchment. Refer to Figure 1 for a description of the key.

\section{The Study Catchment}

The Karoo of South Africa is a landscape of semi-arid plains interspersed with flattopped hills and mountain ranges. River network rejuvenation and associated incision since two periods of tectonic uplift have resulted in almost all catchments in the region being predestined to erosion [54]. Small catchments within this region have been the focus of significant erosion and sedimentation research over the past decade $[31,37,55]$. One of these catchments, Cranemere, was used for model testing. Key features of the catchment can be seen in Figures 3-5 and Table 1.

Table 1. Characteristics of the Cranemere catchment.

\begin{tabular}{ccccccc}
\hline Area $\left(\mathbf{k m}^{2}\right)$ & Elevation (masl) & Drainage Density $\mathbf{( k m / \mathbf { k m } ^ { 2 } )}$ & \multicolumn{3}{c}{ Max Potential Sediment Storage (Kt) } \\
\hline & & & Headwater & Mid-Slope & Lower Slopes & Channel \\
\hline 57 & $753-1507$ & 0.13 & 1500 & 13,500 & 138,000 & 110 \\
\hline
\end{tabular}

The Cranemere catchment $\left(32^{\circ} 31^{\prime} 47^{\prime \prime}\right.$ S; $24^{\circ} 59^{\prime} 37^{\prime \prime}$ E) (Figure 3) contains one of the first farm dams built in the Karoo, in 1843. It therefore provides a lengthy record of sediment delivery rates [37]. The catchment has an area of $57 \mathrm{~km}^{2}$ and its topography is comprised largely of a gently sloping plain with mountains occupying a small area in the north [56]. The drainage system is complex with clearly defined gullies that in certain areas are disconnected from the main channel and the main channel itself becomes indistinct where several alluvial fans and floodouts have significant capacity for sediment storage, as can be seen on Figure 3. Cranemere catchment presented a high potential for sediment storage (Table 1). 


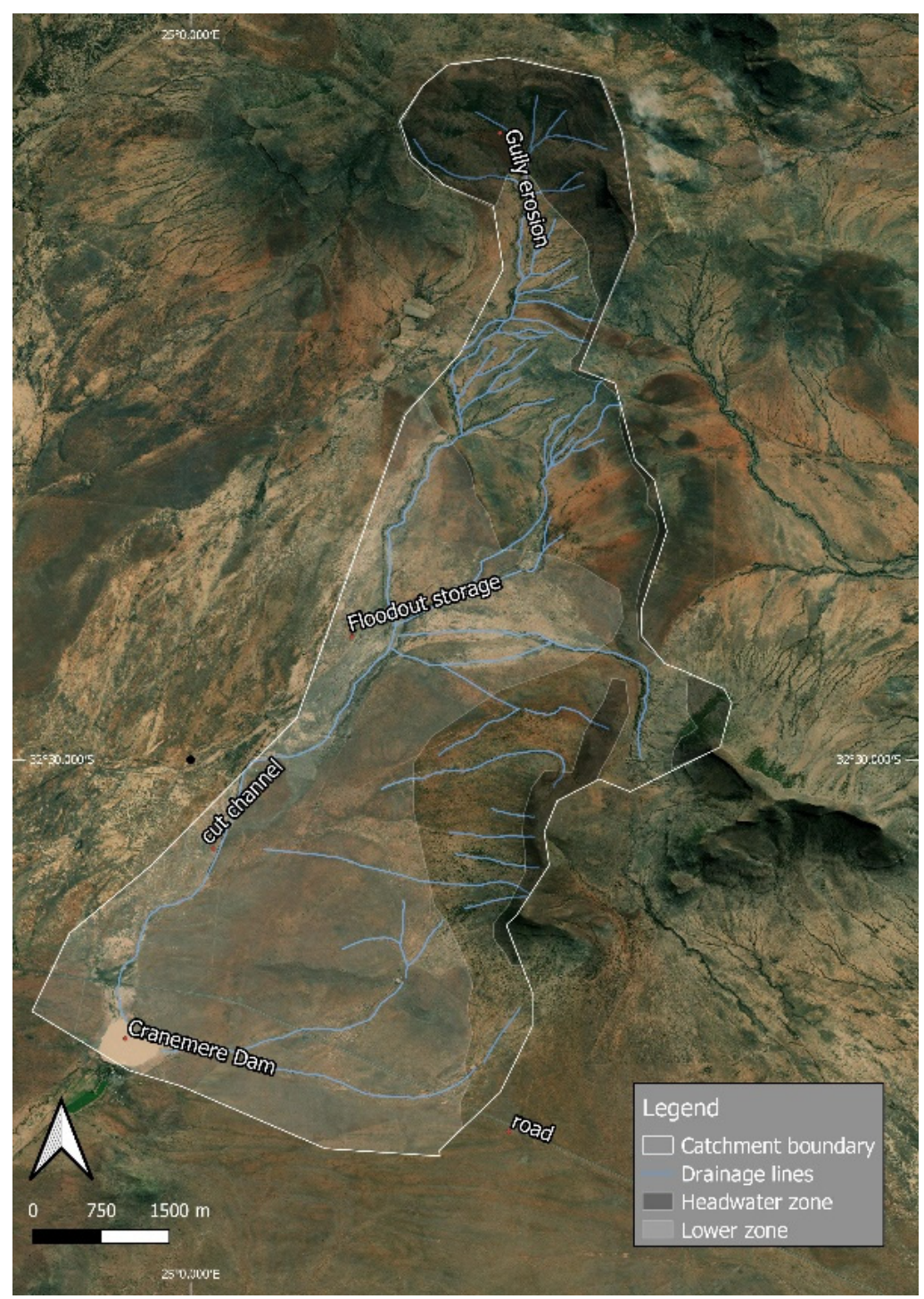

Figure 3. Cranemere dam catchment. The mid-slope zone (not identified) lies between the headwater and lower zones and is characterised by gully erosion.

Foster and Rowntree [37] reconstructed the historical changes in sediment source, transfer and yield for the Cranemere catchment using a palaeo-environmental reconstruction of dam sedimentation rates. The reconstructed sediment yield for the Cranemere catchment showed significant temporal variability. Low yields (less than $25 \mathrm{t} \mathrm{km}^{2} / \mathrm{y}$ ) dominated the period from the 1840s to 1930s, where after sediment yields increased to a peak of just under $250 \mathrm{t} \mathrm{km} / \mathrm{y}$ in the late 1960s. This was followed by a decline to around $150 \mathrm{t} \mathrm{km}^{2} / \mathrm{y}$ up until 2011 [37]. The cumulative yield post 1970 is estimated at $7525 \mathrm{t} / \mathrm{km}$.

Foster and Rowntree [37] suggested that these significant changes in sediment yield through time were due to a combination of changes to rainfall erosivity, land cover and catchment connectivity. They proposed that in the Cranemere catchment a change in connectivity occurred in 1950 when floodouts were reworked and connectivity to stored sediment was increased by a straightened cut channel and road culverts that increased connectivity with the dam (Figure 3).

Three hypotheses were proposed [37] to explain the temporal variation in sediment yields observed in this catchment. The first relates to inherent variation in rainfall, the second to a change in vegetation cover due to overstocking and local cultivation, and the third to a change in connectivity between sediment sources and the catchment outlet. These three scenarios form the basis of model testing as presented in this paper. 

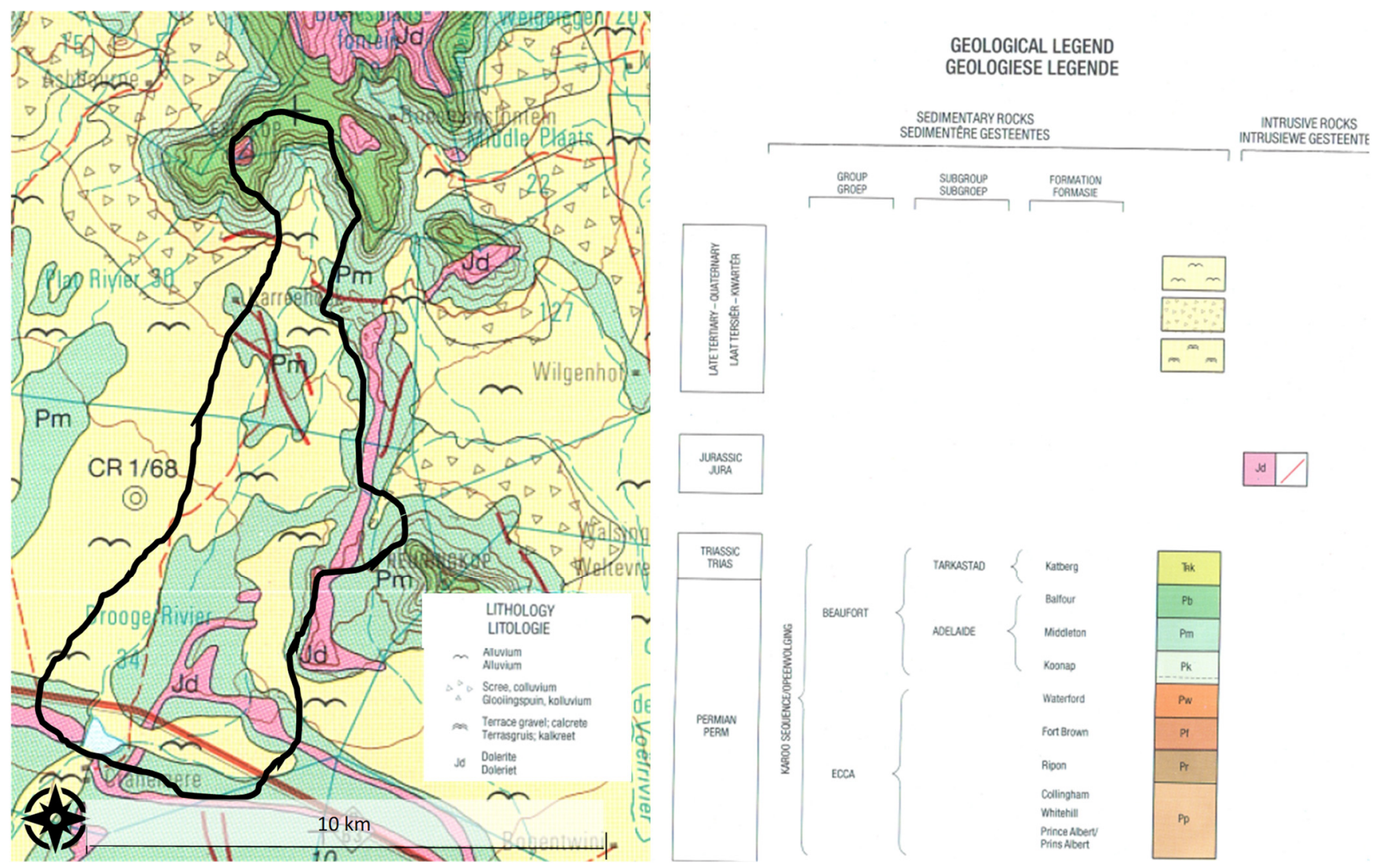

Figure 4. Cranemere dam catchment geological features, indicating the presence of alluvium and dolerite dykes.

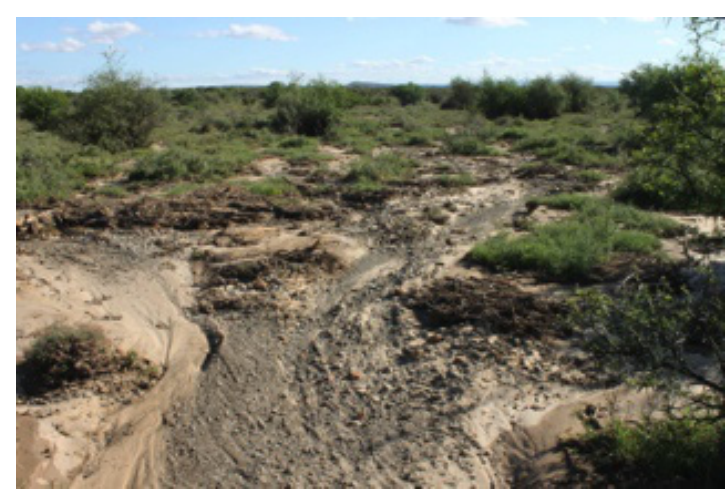

(a)

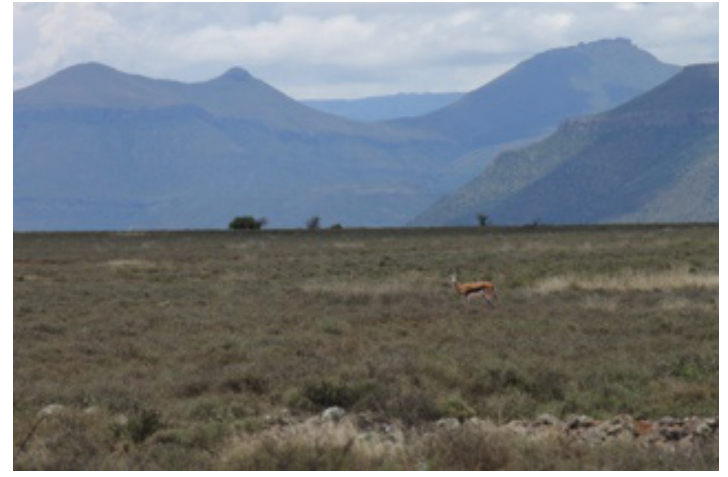

(b)

Figure 5. (a) Floodout formation in the lower zone; (b) Topography of the catchment indicating mountains leading into gentle plains.

\section{Data Preparation}

Data were required for surface flow, erosion and sediment delivery estimation. The surface flow estimation required rainfall data, which was obtained from the Cranemere Farm daily gauge for 1901 to 2004. The catchment zone delineation was based on a topographic assessment using a $30 \times 30 \mathrm{~m}$ Digital Elevation Model (DEM) interpolated from contour data in a Geographical Information System (GIS). This DEM was also used in erosion estimation through the flow accumulation and slope equations, as input to the topography factor [49]. The soil erodibility factor was estimated from land-type data for South Africa, available from the Agricultural Research Council Institute for Soil, Climate and Water [57]. The soil particle size from the land-type data was compared to the table 
presented by Mitchell et al. [50]. The cover factor was estimated from the vegetation type distribution for South Africa from the South African Biodiversity Institutes GIS resource [58]. As this is a coarse scale interpretation of vegetation cover, it was necessary to refer to a Google Earth imagery to determine the actual vegetation characteristics and compare with the table in Wischmeier and Smith [40]. The observed sediment yield data were obtained from the Foster and Rowntree [37] study.

\section{Results}

\subsection{Surface Flow Distribution and Connectivity}

In the Cranemere catchment the highest proportion of the runoff depth distribution occurred in the low catchment zone, or flatter valley bottom areas, due to accumulation from upslope. In the absence of short interval runoff observations, estimated values for the runoff parameters are uncertain, which will affect the accuracy of peak values used in the erosion model and therefore the simulated erosion values. Each catchment zone is expected to contain smaller channels or gullies that increase its connectivity to both the preceding (upslope) zone and the main channel. Although the flow in these channels was not modelled, they were used to represent the transfer of sediment through zones. The estimation of the degree of connectivity, or proportion of "gully connectors", of each catchment zone was determined through field visits to the catchments as well as from relevant literature [37]. A "switch" in connectivity was modelled by adjusting the gully/connectivity proportions.

\subsection{Sediment Yield Estimates and Scenario Testing}

The model was used to test the three hypotheses proposed by Foster and Rowntree [37] to explain changing sediment yields (Table 2). To test the first hypothesis (increases in erosion a response to increased frequency of erosive storms), the model was run with the rainfall input using observed data from the Cranemere catchment (Cranemere Farm gauge) from 1901 to 2004 to reflect the natural variability. Increases in the frequency of large magnitude storm events after 1950 explained certain observed increases in sediment yields in both catchments. The second hypothesis, that increased erosion was a response to a decreased vegetation cover, was tested by reducing the cover factor from 0.5 to 0.3 . The simulation used the observed rainfall as for simulation 1 . Decreasing the vegetation cover factor after 1950 added significantly to sediment delivery to the dams. However, the modelled results oversimulated erosion (Table 3).

Table 2. Scenarios for model testing.

\begin{tabular}{|c|c|c|}
\hline Scenario & Description & Results \\
\hline 1 & No parameter changes & $\begin{array}{l}\text { Rainfall was an important driver for the observed increase in sediment yield } \\
\text { in the latter half of the century but did not explain all of this increase. Other } \\
\text { variables will also be important. }\end{array}$ \\
\hline 2 & Decrease in vegetation cover after 1970 & $\begin{array}{l}\text { Changing the vegetation cover impacts directly on erosion estimates, which } \\
\text { were overestimated, with a n increase in sediment delivery, but modelled } \\
\text { sediment yields underestimated observed rate. }\end{array}$ \\
\hline 3 & Increase in landscape connectivity after 1970 & $\begin{array}{l}\text { Increased connectivity meant that there were more sediment delivery events } \\
\text { and an improved correlation with the observed sediment yield. }\end{array}$ \\
\hline
\end{tabular}

The third hypothesis was tested by changing the connectivity factor from 0.1 to 0.5 in the mid-slope and low catchment zones. The modified cover factor was retained as for simulation 2 . This combination gave the best relationship between observed and simulated sediment yield (Table 3). The best correlation with observed yield was obtained when a connectivity switch with cover factor change was included in the model. The increased connectivity meant that there were more sediment delivery events as the catchment became more active. Erosion and sediment yield were in balance by the end of the period indicating all eroded sediment was being delivered to the dam (Figure 6). 
Table 3. Comparison of results for scenario testing in the Cranemere catchment.

\begin{tabular}{|c|c|c|c|c|c|c|}
\hline & \multicolumn{2}{|c|}{ Scenario 1} & \multicolumn{2}{|c|}{ Scenario 2} & \multicolumn{2}{|c|}{ Scenario 3} \\
\hline & Pre-1970 & Post-1970 & Pre-1970 & Post-1970 & Pre-1970 & Post-1970 \\
\hline Cumulative modelled erosion (t. $\mathrm{km}^{2}$ ) & 4000 & 10,000 & 5500 & 13,000 & 3000 & 10,000 \\
\hline Cumulative modelled sediment yield (t. km²) & 2000 & 3500 & 2000 & 4000 & 4000 & 10,000 \\
\hline Cumulative observed sediment yield (t.km²) & 2000 & 10,000 & 2000 & 10,000 & 2000 & 10,000 \\
\hline
\end{tabular}

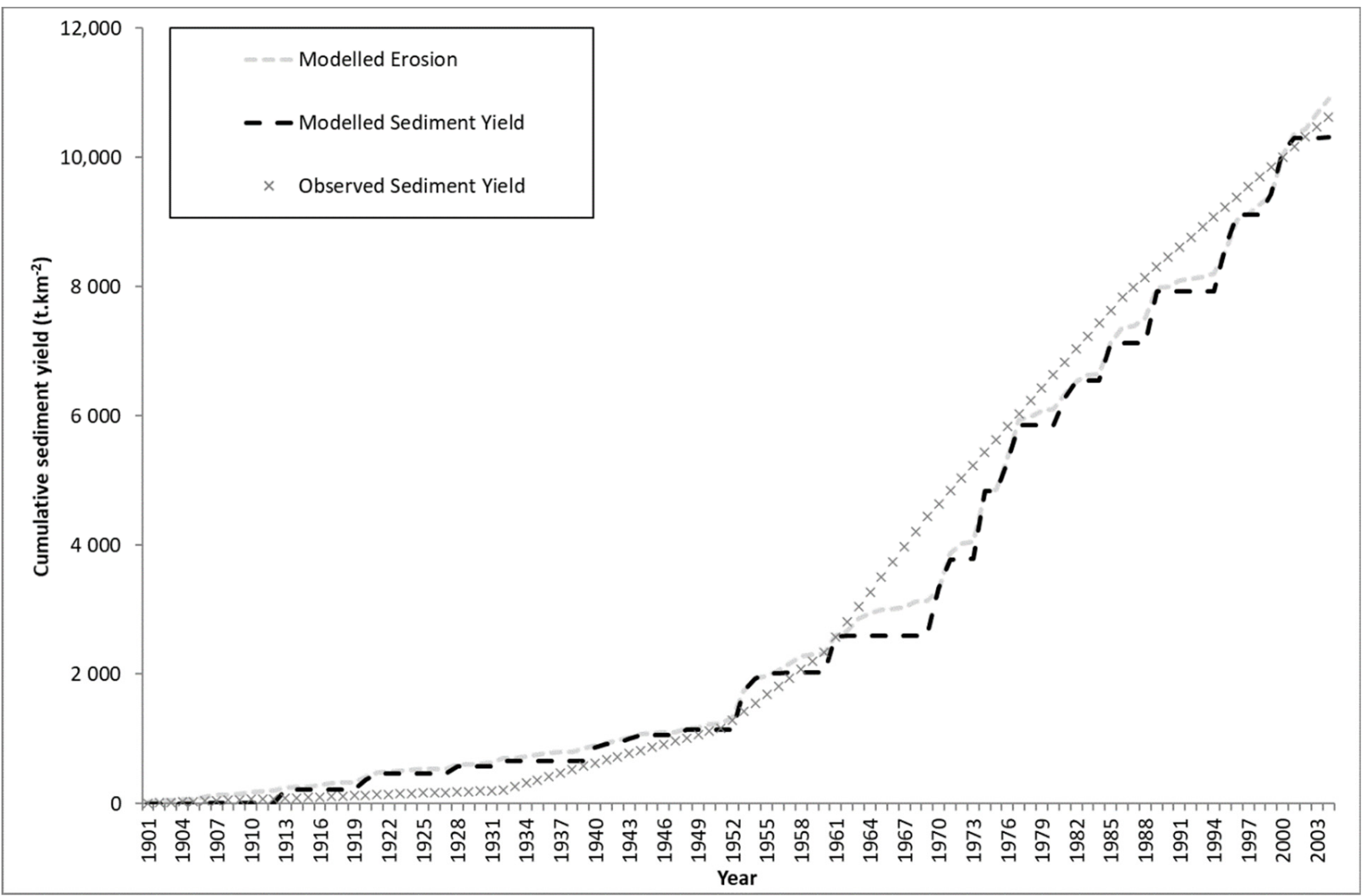

Figure 6. The cumulative modelled erosion and sediment yield versus cumulative observed sediment yield for the Cranemere catchment when incorporating a "switch" in connectivity.

The "flashiness" of flow was represented as significant peaks in surface flow throughout the time series. These were important events in the model as they acted to effectively "flush out" sediment from temporary stores. An increasing trend of frequency and magnitude of runoff events during the latter half of the time series in response to the increase in the amount and intensity of rainfall was noted (Figure 7). The erosion and sediment yield outputs for the Cranemere catchment closely followed the surface flow, although the large runoff event in 1932 resulted in a comparatively small sediment yield event due to the start of the time series representing a disconnected catchment (Figure 7). The sediment delivery outputs also had extreme "pulses" of sediment delivery, following periods of low flow. 


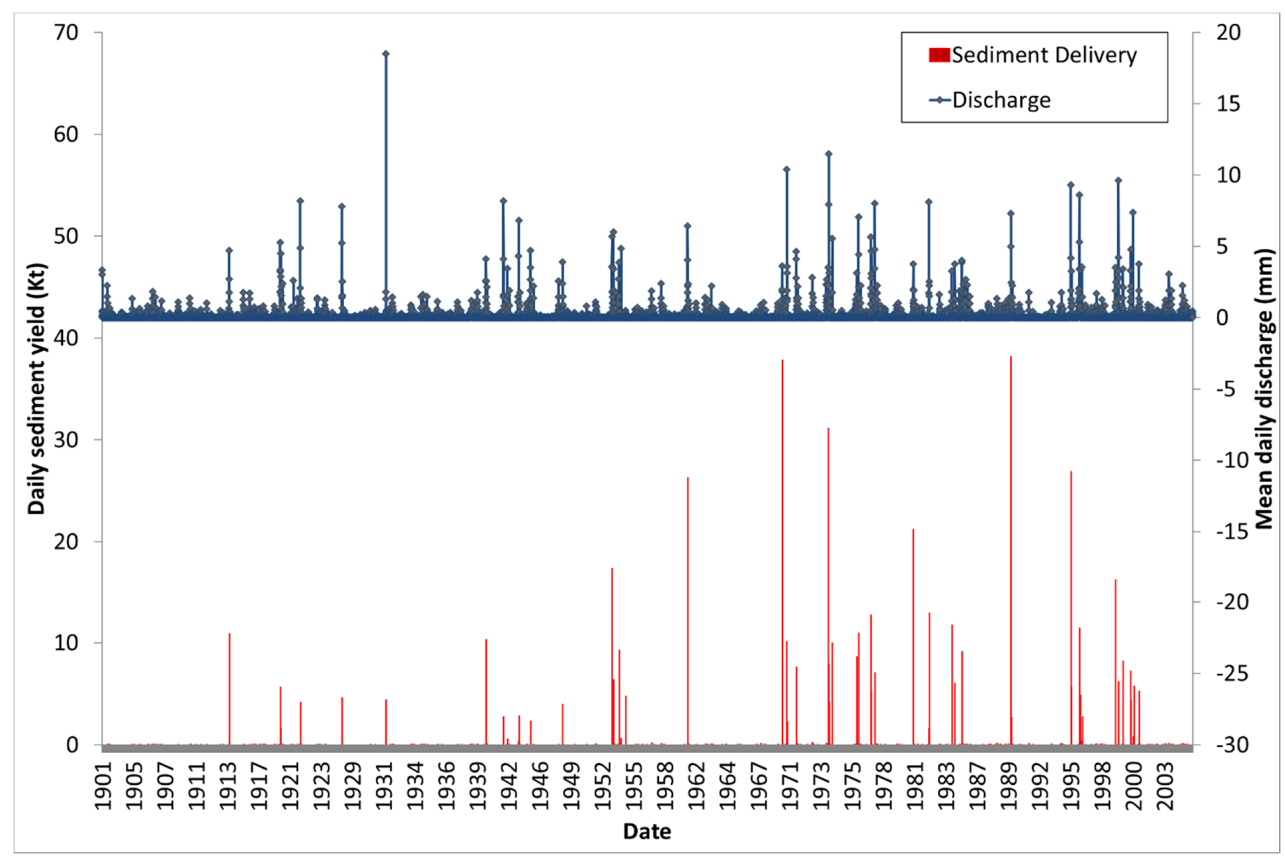

Figure 7. A comparison of daily sediment yield and discharge outputs for the Cranemere catchment.

An inspection of individual runoff events indicates that a peak in sediment yield occurred on the day following the peak in surface flow and erosion (Figure 8). This represented the "sediment cascade" as sediment would move through individual storage zones before being released as sediment delivered at the catchment outlet. The "flushing" effect, observed when a second event follows closely on a previous one, was also evident from the modelled output (Figure 6). Runoff from the second event carried less sediment as stores had been depleted by the first one. These examples indicate that both runoff and sediment availability are driving factors in the sediment delivery component of the model.

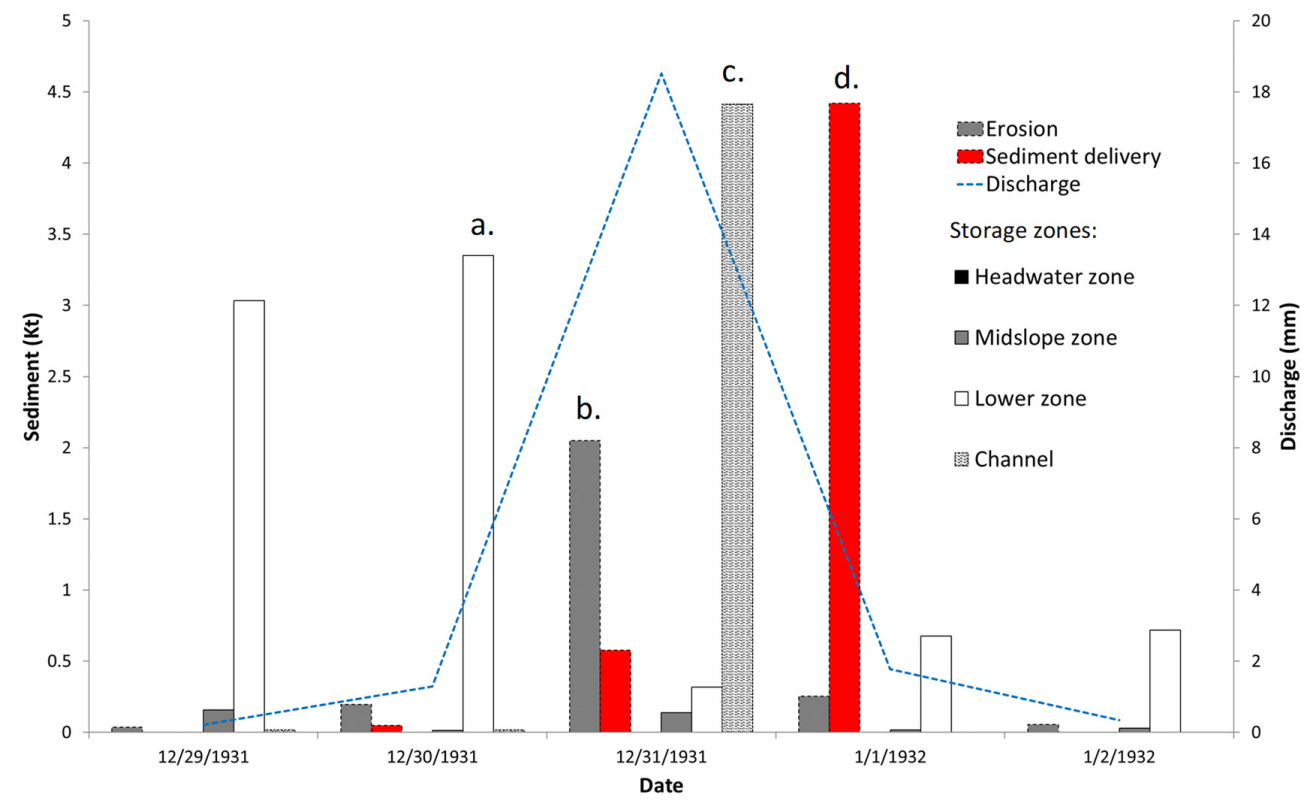

Figure 8. The model outputs for a four-day event in the Cranemere catchment indicating the cascade of sediment delivery through sediment stores. Stored sediment in the lower zone (a) and eroded sediment during the discharge peak (b) moves to the lower zone (c) and finally leaves the catchment as sediment yield (d). 


\section{Discussion}

\subsection{Extent to Which the Model Was Successful}

The qualitative understanding of semi-arid region hydrology and geomorphology assisted model development through representation of four criteria: representation of episodic flow, operation at short time steps in response to short lived storm events, compatibility with Pitman rainfall-runoff model and limiting complexity through using few parameters. The performance of the model in relation to the former two criteria are discussed below.

The representation of variable rainfall was reliant on the daily rainfall data input to the Pitman rainfall-runoff model. Daily rainfall data may be, in practical terms, the most appropriate data to apply to the Pitman model; however, storms are generally short lived in semi-arid areas, often lasting less than an hour. High intensity, short duration rainfall is most effective in detaching soil and generating overland flow. Whilst this characteristic was not necessarily represented, the "flashiness" of flow on a daily time scale was represented through significant peaks over the time series. These were important events in the model as they acted to effectively "flush out" sediment from temporary stores. Although a trend of increasing rainfall magnitude and intensity was evident during the latter half of the century, this was not considered to be the only factor causing an increased sediment yield.

The Cranemere catchment has a low relief terrain as most of the catchment has a gentle gradient, providing a large capacity for temporary storage in the form of floodouts and alluvial fans. This difference in relief was represented through the topography factor. In general, topography may determine the degree of connectedness or level of sediment yield of a catchment. A steep catchment tends to be more connected than a catchment in gently sloping terrain [33]. High relief promotes the generation of sediment and efficiency of sediment conveyance of hillslope-derived sediments, whilst in contrast, a low relief, low drainage density catchment, with relatively small source areas and extensive sediment stores, represents a disconnected catchment. In a low energy setting, sediment conveyance is restricted to episodic, infrequent, large magnitude events, with temporary stores having the potential to be maintained for many years.

The use of a storage and connectivity component in the model was considered important as sediment which is made available by the erosion model does not immediately reach the catchment outlet, but rather moves within a "sediment cascade". This was represented through the storage zones and gully or channel connectivity within each zone. Only during infrequent, high magnitude events would the entire catchment area be considered effectively connected and the maximum storage zones would be "flushed" of stored sediment.

The Cranemere catchment experienced significant changes in catchment connectivity during its sedimentation history. This related to the reworking of landscape units which act to disconnect a catchment [33]. The temporal variability of catchment disconnectivity is related to the size and sedimentary composition of the landscape unit or temporary storage zone and the magnitude-frequency of geomorphically effective events that rework these obstructions to sediment delivery. This provides a conceptualisation of a catchment system reliant on event-driven connectivity to rework temporary sediment stores. The spatial pattern of these landscape units influences the timeframe over which sediments are reworked in different landscape compartments. In the Cranemere catchment, it was hypothesised by Foster and Rowntree [37] that a change in connectivity occurred in 1950 when the main channel was connected to the catchment outlet. The "sediment cascade" component of the model is reliant on both available sediment and the magnitude of the runoff event. By incorporating a "switch" in catchment connectivity in the model, it was possible to represent this important characteristic in the Cranemere catchment. 
Without the incorporation of the storage zones, an erosion model would overestimate sediment yield. Model testing showed that although runoff was a significant driver of erosion, for sediment delivery the activation of storage zones was a more important control. The model showed connectivity changes to be more important for sediment delivery than changes to vegetation cover or rainfall. The inclusion of a "switch" allowed the incorporation of landscape scale changes to catchment connectivity that were able to model the observed increases in sediment delivery.

\subsection{Likely Source of Error}

In South Africa, as is common in many underdeveloped countries, model optimisation is difficult due to the issue of finding consistency in parameter values in a region where the reliability and accuracy of input data are questionable [59]. Optimisation processes tend to generate parameter values that account for errors in the data rather than the real signal. An understanding of the model and sediment system is critical to the calibration exercise to reduce these errors.

A limitation of the model is that sediment is assumed to travel sequentially through the storages of three runoff zones before reaching the main channel and delivering sediment to the outlet. In reality, different parts of the catchment are better connected to the main channel than is represented in the model, especially when it is applied to a large catchment. The implication is that the sediment routing process requires modification when applied to larger catchments, perhaps by partitioning into smaller sub-basins whose sediment outputs are combined through a further "main channel" delivery storage. Application of the model to a much larger catchment was less successful than when applied to smaller catchments [36].

Transmission losses are an important component of semi-arid hydrology [60-64]. Transmission losses would be expected in the larger, flatter Cranemere catchment and the flow frequency characteristics of the lower catchment zone will be different from those of the headwater catchment zone. However, the model uses a single input time series to determine these characteristics, indicating that surface flow characteristics have not been effectively represented in the surface flow component of the model. The effects of transmission losses are therefore not accounted for within a single sub-catchment of the hydrological model. This represents a significant limitation to the surface flow estimation component and, in turn, the erosion and sediment delivery components. This can be overcome by partitioning the catchment into smaller sub-catchments and including an additional channel sediment storage-routing function to link them.

The runoff component of the erosion model is based on estimates of the peak instantaneous surface runoff rate with a fixed power function. The instantaneous runoff rate has to be estimated from the daily input-flow data and relies on assumptions about the likely shape of hydrographs at sub-daily time scales (through parameter values). In the absence of adequate data to determine the relevant parameters, there is high uncertainty concerning the runoff inputs into the erosion model.

\subsection{Comparison with Other Models}

The USLE, RUSLE and Soil Loss Estimation Model for Southern Africa (SLEMSA) [65] have been the most widely applied empirical models in southern Africa [66]. After sensitivity testing, the dynamic and flexible approach of the RUSLE was found to be more advantageous than the strict empirical structure of the USLE and SLEMSA [67]. The user interface has also improved over the years with the RUSLE incorporating GIS and algorithms to describe topographic and hydrological factors. This has been beneficial in the use of the RUSLE for regional erosion studies [68] as an input to the Revised Sediment Yield Map for South Africa [69]. The use of empirical models as a "screening tool" in data-poor regions such as South Africa has meant that they are more popular than deterministic models [67]. Their low data requirements and practical applicability have also made them more attractive to managers [41]. 
Empirical USLE-derived models have also been incorporated into continuous simulation models such as ACRU developed for application to South African catchments [17] and SWAT [16]. The USLE-related component of the models estimates erosion from the catchment surface; sediment delivery to the catchment outlet is estimated through a sediment delivery ratio that expresses the percentage relationship between annual sediment yield and the modelled annual gross erosion [15]. In the ACRU Modelling System, the sediment yield from a catchment or land use unit is computed with the MUSLE imbedded in the modelling system [70]. ACRU does not model gully erosion or provide for temporary storage. Therefore, the modelled absolute and relative sediment yields will only be representative of erosion characteristics. The SWAT model uses the RUSLE in the modelling system, with similar limitations as ACRU [71]. Le Roux [71] investigated the sediment yield potential of the sub-humid Tsitsa catchment, a tributary of the Mzimvubu in the in the Eastern Cape, using a combination of the ARC-Swat-12 model to simulate rill and inter-rill erosion and a gully module that estimated sediment yield from mapped changes to gully extent and sediment delivery based on gully connectivity. Storage was not considered.

One strength of empirical models based on the application of a sediment delivery ratio to USLE-derived erosion estimates is their use for assessing the impact of land use change on sediment yield. This does not account for change to landscape connectivity and storage, which are important drivers of sediment yield, especially in semi-arid catchments. Although the use of simple empirical models is considered practical by water resource managers, the limited understanding and modelling of sediment storage and catchment connectivity will mean that they will focus on erosion factors (i.e., rainfall, soil, vegetation or topography) rather than sediment delivery factors (i.e., landscape connectivity and storage). The SASYM allows managers to look beyond erosion factors and consider sediment storage and delivery. This is an important consideration in semi-arid regions and reinforces Fryirs' [5] conclusion that an understanding of the internal dynamics of sediment storage in a catchment proceeds certain ways to solving the sediment delivery problem.

\subsection{Model Applicability}

Although the SASYM was developed with the Pitman rainfall-runoff model in mind, it is applicable for use with other daily time step hydrological models. The runoff inputs are included in SASYM as a text file; therefore, runoff inputs from other hydrological models can be used if they are prepared with a compatible text file.

It is planned to include SASYM within the Water Quality Systems Assessment Model (WQSAM) [70]. Apart from sediment itself being an important water quality variable affecting water for use by humans and aquatic ecosystems [2-5,72], there are important interactions between sediment and other key water quality variables, such as pesticides [73], metals [74] and nutrients [75]. It is therefore important to include sediment within a water quality model to accurately represent these interactions.

Although designed specifically for semi-arid regions, the conceptual framework of SASYM can also be applied to more humid areas. Gwapedza et al. [76] applied a modified version of Bryson's [36] model to the Inxu, a tributary of the sub-humid Tsitsa River catchment, for which short-term suspended sediment data were available. Adding a storage component to the MUSLE model significantly improved sediment yield estimates. Connectivity was not considered by these authors [76], despite the ubiquitous gully networks.

Understanding the impact of climate change on landscape processes is critical for determining what strategies are necessary for managing land and water resources in the future [26]. Sediment dynamics of semi-arid catchments are complex, making it difficult to predict how climate change will affect landscape processes and dynamics. Given that extreme magnitude runoff events dominate sediment delivery, focusing on the impact of climate change on extreme events is crucial [52]. However, application of the SASYM model to two semi-arid catchments has supported the notion that sediment processes are not only controlled by the direct effects of climate, but also by indirect structural changes to 
the landscape [36]. Changes in connectivity can mediate the effect of changes in sediment flux associated with an altered flow regime. Climate change, therefore, may be manifested through its effects upon landscape connectivity [52]. Moreover, change can cascade through a system such that it is important to consider the spatial and temporal scales of a catchment that can cause time lags in the system response.

\section{Conclusions}

The SASYM is useful as it uses an overarching framework of connectivity to deal with the issue of scale. The concept of connectivity reflects the interactions and feedbacks of different catchment compartments or "catchment zones" under changing conditions and will determine the propagation of the effects of the change as the structure of the landscape is transformed [77]. This assists land and water resource managers with a conceptual understanding of change at a landscape scale, which will be useful in collaboration and decision making (i.e., for the South African NatSilt Programme). The SASYM will also act as an informative tool for other water quality models. As the model is run on a daily timescale, water quality predictions may be related to specific sediment delivery events. The "sediment cascade" component of the model will allow for the identification of particular storage zones where nutrients may collect along with sediments. Water resource managers in semi-arid, developing countries are faced with significant infrastructural, logistical and environmental challenges with limited resources with which to face these challenges. Models need to be designed to give useful predictions using available observed data. This constrained the development of the SASYM model to be for situations with limited data. Typically for model development under such data constraints, a strategy of requisite simplicity [78] is followed. Here, only the most important processes explaining the majority of variation in the observed data are included, with the results of a model generated at spatial and temporal scales that are useful for water resources management, and not necessarily for rigorous scientific research at for example the plot scale.

The SASYM is representative of semi-arid catchments, where sediment delivery usually occurs during infrequent, high magnitude runoff events. This model has potential to fill a gap in the water resources modelling tools in regions, where available models are either too complex for data-poor environments or do not account for important processes within a semi-arid catchment. It provides a simple representation of the stochastic nature of erosion and sediment delivery over large spatial and temporal scales. It is considered a useful tool for long-term management of sedimentation in reservoirs and short-term management of water quality in semi-arid regions where water is a limited resource.

Author Contributions: Conceptualization, L.L., D.H. and K.R.; methodology, L.L., D.H. and K.R.; software, D.H.; validation, L.L. and D.H.; formal analysis, L.L., D.H. and K.R.; investigation, L.L., D.H. and K.R.; data curation, L.L. and A.S.; writing-original draft preparation, L.L., K.R. and A.S.; writing-review and editing, L.L. and K.R.; visualization, L.L. and K.R. All authors have read and agreed to the published version of the manuscript.

Funding: The APC was funded by the Water Research Commission under the National Siltation Management Strategy for Dams in South Africa project.

Data Availability Statement: Refer to [34] for data used in this study.

Conflicts of Interest: The authors declare no conflict of interest.

\section{Appendix A}

Daily flows $\left(\mathrm{m}^{3} \mathrm{~s}^{-1}\right)$ are required for the erosion estimation. These can either be an unbroken time series of observed daily flow, daily flow estimated from a daily hydrological model such as the Agricultural Catchments Research Unit (ACRU) model [17], or monthly flow simulated from a monthly hydrological model such as the Pitman Model [38] disaggregated to daily using a monthly to daily disaggregation routine (e.g., [39]). 
Daily flows are separated into surface and subsurface flow fractions, namely surface flow, interflow and groundwater flow, all in $\mathrm{m}^{3} \mathrm{~s}^{-1}$, using the baseflow separation method by Hughes et al. [51].

The catchment surface flow volume is calculated from surface flow (Flows):

$$
\text { Vsf }=[\text { Flow }] \_s \times 0.0036 \times 24,
$$

where Vsf is the surface flow volume in million cubic meters (MCM) per day.

The storm duration associated with surface flow on each day is then calculated:

$$
\mathrm{D}=\left[\mathrm{D} \_ \text {Scale }(\mathrm{Vsf})\right]^{\mathrm{DP}}+\mathrm{D} \_ \text {con, }
$$

where D is the duration (hours), and Dscale, DP and Dcon are the scaling, power and constant parameters, respectively, for calculating the duration. All three runoff zones are assumed to have the same duration of runoff.

The peak discharge for each runoff zone is calculated assuming a double triangle shaped hydrograph:

$$
\begin{gathered}
\text { Q_Hp }=(2 \times[\text { Flow]_s } \times 24) /(0.75 \times \mathrm{D}), \\
\text { Q_Mp }=(2 \times \text { Q_Hp } \times 24) /(0.75 \times \mathrm{D}), \\
\text { Q_Lp }=(2 \times \text { Q_Mp } \times 24) /(0.75 \times \mathrm{D}), \\
\text { q_Hp }=\left(\left(\mathrm{Q} \_H p \times 3.6\right) / \text { A_H }\right), \\
\text { q_Mp }=\left(\left(\mathrm{Q} \_\mathrm{Mp} \times 3.6\right) / \text { A_M }\right), \\
\text { q_Lp }=\left(\left(\mathrm{Q} \_L p \times 3.6\right) / \text { A_L }\right),
\end{gathered}
$$

where QHp, QMp, and QLp are the peak runoff flows for the high, medium and low runoff zones, respectively (in $\left.\mathrm{m}^{3} \mathrm{~s}^{-1}\right), \mathrm{AH}, \mathrm{AM}$ and $\mathrm{AL}$ are the areas $\left(\mathrm{km}^{2}\right)$ of the high, middle and low runoff zones, respectively, and qHp, qMp and qLp are the peak runoff depths for the high, medium and low runoff zones, respectively (in $\mathrm{mm} \mathrm{h}^{-1}$ ).

The runoff depths for the high, medium and low runoff zones are then computed based on the assumption that the high runoff zone generates $75 \%$ more runoff than the moderate runoff zone, which in turn is assumed to generate $75 \%$ more than the low runoff zone:

$$
\begin{gathered}
\text { Depth }=\left([\text { Flow }] \_s \times 86.4\right) / \text { A_H, } \\
{[\text { Depth }] \text { H }=\text { Depth } /(H+(M / 1.75)+(\text { L } / 3.0625)),} \\
{[\text { Depth }] \_M=[\text { Depth }] \text { H } / 1.75,} \\
{[\text { Depth }] L=[\text { Depth }] \text { H } / 3.0625,}
\end{gathered}
$$

where Depth is the runoff depth for the entire catchment $\left(\mathrm{mm} \mathrm{day}^{-1}\right), \mathrm{H}, \mathrm{M}$ and $\mathrm{L}$ are the proportions of the entire catchment area falling within the high, medium and low runoff zones, respectively, and DepthH, DepthM and DepthL are the runoff depths $\left(\mathrm{mm} \mathrm{day}^{-1}\right)$ for the high, medium and low runoff zones, respectively.

Daily sediment availability is calculated using the Modified Universal Soil Loss Equation (MUSLE) [44].

$$
\mathrm{SA}=\mathrm{R} \times \mathrm{LS} \times \mathrm{K} \times \mathrm{C} \times \mathrm{P}
$$

where SA is the daily sediment availability (tons ha ${ }^{-1}$ ), $\mathrm{R}$ is the runoff factor, $\mathrm{C}$ is the cover factor, LS is the topography factor, $\mathrm{K}$ is the soil erodibility factor and $\mathrm{P}$ is the practice factor. Equation A13 would be run separately for each runoff zone, where LS, K, C and P would be related to the characteristics of the catchment area in a specific zone, and $\mathrm{R}$ would also be related to a specific runoff zone; therefore, for the high runoff zone for example:

$$
\mathrm{R} \_\mathrm{H}=1.586 \times\left[\left(\left[\text { Depth] } \_\mathrm{H} \times \mathrm{q} \_\mathrm{Hp}\right)\right]^{0.56} \times \mathrm{A} \_\mathrm{H}^{0.12} .\right.
$$




\section{Appendix B}

The maximum storage capacity for each runoff zone as well as for the main channel is calculated by:

$$
\text { S_max }=\mathrm{A} \times \mathrm{p} \times \mathrm{d} \text {, }
$$

where Smax is the maximum sediment storage capacity $(\mathrm{kg})$ of the runoff zones or main channel, A is the area $\left(\mathrm{m}^{2}\right)$ of the runoff zone of channel, $\mathrm{p}$ is the bulk density $\left(\mathrm{kg} \mathrm{m}^{2}\right)$ and $\mathrm{d}$ is the maximum depth $(\mathrm{m})$ of the stored sediment.

The proportion of gully or channel storage in each runoff zone is then calculated:

$$
\text { C_prop }=\text { LnDD, }
$$

where Cprop (constrained between 0.1 and 0.8 ) is the proportion of the total storage in a runoff zone that is assumed to be represented by gully or channel storage and DD is the drainage density $\left(\mathrm{km} \mathrm{km}^{2}\right)$ of the channel features in that zone.

Sediment is added to the three slope storage zones during each time interval of the model:

$$
\mathrm{SS}(\mathrm{t})=\mathrm{SS}\left(\mathrm{t}^{-1}\right)+\mathrm{S} \_ \text {input, }
$$

where $\mathrm{SS}\left(\mathrm{t}^{-1}\right)$ is the sediment storage at the end of the previous time interval, $\mathrm{SS}(\mathrm{t})$ is the new storage (before transport of other storages) and Sinput is the sediment generated form the soil loss estimation procedure described in Appendix A.

The output from each storage component is calculated using the peak surface runoff (qsed $\mathrm{mm} \mathrm{h}^{-1}$ ) for that runoff zone relative to the maximum mean daily total flow depth (qmax $\mathrm{mm} \mathrm{h}^{-1}$ ) for the whole catchment (over the whole time series) and a threshold flow depth $\left(\mathrm{qt}, \mathrm{mm} \mathrm{h}^{-1}\right)$, as well as a power function for the amount of sediment currently in storage relative to the maximum possible storage.

For the main channel storage, the peak runoff value is based on the total flow (not only surface runoff) depth during the day for the whole catchment. The maximum mean daily total flow depth is pre-calculated from the full time series of flow data input from the hydrological model.

If qsed > qt then:

$$
\text { S_out }=(\text { q_sed-q_t }) /(\text { q_max-q_t }) \times S S \times\left[\left([S S / S] \_m a x\right)\right]^{\text {pow }}
$$

For the three slope sediment storage components the Cprop value (i.e., the proportion of total sediment storage for the runoff zone that is considered to be in channel features) is used to determine the destination of the sediment delivery. Sout $\times$ Cprop is added to the channel storage within the same runoff zone, whereas Sout $\times(1-$ Cprop $)$ is added to the slope storage of the next runoff zone in the cascade. The outputs from the channel storages are directed to the next channel storage in the cascade, whereas all of the outputs from the lower runoff zone are directed to the main channel. The outputs from the main channel become the final sediment delivery for the total catchment.

\section{References}

1. Newcombe, C.P.; Macdonald, D.D. Effects of Suspended Sediments on Aquatic Ecosystems. N. Am. J. Fish. Manag. 1991, 11, 72-82. [CrossRef]

2. Lal, R. Soil erosion impact on agronomic productivity and environmental quality. Crit. Rev. Plant Sci. 1998, 17, 319-464. [CrossRef]

3. Ananda, J.; Herath, G. Soil erosion in developing countries: A socio-economic appraisal. J. Environ. Manag. 2003, 68, 343-353. [CrossRef]

4. Montgomery, D.R. Soil erosion and agricultural sustainability. Proc. Natl. Acad. Sci. USA 2007, 104, 13268-13272. [CrossRef]

5. Walling, D.E. The Impact of Global Change on Erosion and Sediment Transport by Rivers: Current Progress and Future Challenges; UNESCO: Paris, France, 2009.

6. Morris, G.L. Classification of Management Alternatives to Combat Reservoir Sedimentation. Water 2020, 12, 861. [CrossRef]

7. Kastridis, A.; Kamperidou, V. Influence of land use changes on alleviation of Volvi Lake wetland (North Greece). Soil Water Res. 2016, 10, 121-129. [CrossRef]

8. Maina, C.W.; Sang, J.K.; Raude, J.M.; Mutua, B.M.; Moriasi, D.N. Sediment distribution and accumulation in Lake Naivasha, Kenya over the past 50 years. Lakes Reserv. Res. Manag. 2019, 24, 162-172. [CrossRef] 
9. Vásquez-Méndez, R.; Ventura-Ramos, E.; Oleschko, K.; Hernández-Sandoval, L.; Angel, M. Soil Erosion Processes in Semiarid Areas: The Importance of Native Vegetation. In Soil Erosion Studies; IntechOpen: London, UK, 2011.

10. Merritt, W.; Letcher, R.; Jakeman, A. A review of erosion and sediment transport models. Environ. Model. Softw. 2003, 18, 761-799. [CrossRef]

11. Vanmaercke, M.; Poesen, J.; Broeckx, J.; Nyssen, J. Sediment yield in Africa. Earth-Sci. Rev. 2014, 136, 350-368. [CrossRef]

12. Robinson, A.R. The relationship between soil erosion and sediment delivery. In Proceedings of the Paris Sym-Posium on Erosion and Solid Matter Transport in Inland Waters; IAHS: Orlando, FL, USA, 1977; pp. 159-167.

13. Wolman, M.G. Changing needs and opportunities in the sediment field. Water Resour. Res. 1977, 13, 50-54. [CrossRef]

14. Meade, R.H. Sources, Sinks, and Storage of River Sediment in the Atlantic Drainage of the United States. J. Geol. 1982, 90, 235-252. [CrossRef]

15. Walling, D. The sediment delivery problem. J. Hydrol. 1983, 65, 209-237. [CrossRef]

16. Neitsch, S.L.; Arnold, J.G.; Kiniry, J.R.; Williams, J.R. Soil and Water Assessment Tool Theoretical Documentation; Agricultural Research Service: Temple, TX, USA, 2005.

17. Schulze, R.E. ACRU: Background Concepts and Theory. In ACRU Report No. 36; Depterment Agricultural Engineering, University of Natal: Pietermaritzburg, South Africa, 1989.

18. Fryirs, K.A.; Brierley, G.J. Geomorphic Analysis of River Systems: An Approach to Reading the Landscape; Wiley: Hoboken, NJ, USA, 2012; pp. 1-8.

19. Schumm, S.A. The Fluvial System; Wiley: New York, NY, USA, 1977.

20. Lal, R. Soil degradation by erosion. Land Degrad. Dev. 2001, 12, 519-539. [CrossRef]

21. Beven, K. Rainfall-Runoff Modelling: The Primer; John Wiley \& Sons: Chichester, UK, 2001.

22. Ludwig, J.A.; Wilcox, B.P.; Breshears, D.D.; Tongway, D.J.; Imeson, A.C. Vegetation patches and run-off-erosion as interacting ecohydrological processes in semiarid landscapes. Ecology 2005, 86, 288-297. [CrossRef]

23. Knighton, A.D.; Nanson, G.C. Distinctiveness, diversity and uniqueness in arid zone river systems. In Arid Zone Geomorphology: Process, Form and Change in Drylands, 2nd ed.; Thomas, D.S., Ed.; John Wiley \& Sons: Chichester, UK, 1997; pp. $185-203$.

24. Bryan, R.; Yair, A. Perspectives on studies of badland geomorphology. In Badland Geomorphology and Piping; Bryan, R., Yair, A., Eds.; Geo Books: Norwich, UK, 1982.

25. Ferguson, B.K. Erosion and sedimentation control in regional and site planning. J. Soil Water Conserv. 1981, 36, $199-204$.

26. Grenfell, S.; Grenfell, M.; Rowntree, K.; Ellery, W. Fluvial connectivity and climate: A comparison of channel pattern and process in two climatically contrasting fluvial sedimentary systems in South Africa. Geomorphology 2014, 205, 142-154. [CrossRef]

27. Tooth, S. Dryland Fluvial Environments: Assessing Distinctiveness and Diversity from a Global Perspective. Treatise Geomorphol. 2013, 612-644. [CrossRef]

28. Thornes, J.B. Channel changes in ephemeral streams: Observations, problems and models. River Channel Chang. 1997, 317-335.

29. McCarthy, T.S.; Ellery, W.N. The Okavango Delta. Trans. R. Soc. S. Afr. 1998, 53, 157-182. [CrossRef]

30. Hooke, J. Coarse sediment connectivity in river channel systems: A conceptual framework and methodology. Geomorphology 2003, 56, 79-94. [CrossRef]

31. Boardman, J.; Foster, I.; Rowntree, K.; Favis-Mortlock, D.; Mol, L.; Suich, H.; Gaynor, D. Long-term studies of land degradation in the Sneeuberg uplands, eastern Karoo, South Africa: A synthesis. Geomorphology 2017, 285, 106-120. [CrossRef]

32. van der Waal, B.; Rowntree, K. Landscape Connectivity in the Upper Mzimvubu River Catchment: An As-sessment of Anthropogenic Influences on Sediment Connectivity. Land Degrad. Dev. 2018, 29, 713-723. [CrossRef]

33. Fryirs, K.A.; Brierley, G.J.; Preston, N.J.; Kasai, M. Buffers, barriers and blankets: The (dis)connectivity of catchment-scale sediment cascades. Catena 2007, 70, 49-67. [CrossRef]

34. Graf, W.L. Fluvial Processes in Dryland Rivers; Springer Science and Business Media LLC: Berlin, Germany, 1988.

35. Trimble, S.W. Catchment sediment budgets and change. In Changing River Channels; Gurnell, A., Petts, G., Eds.; John Wiley \& Sons: Chichester, UK, 1995; pp. 201-215.

36. Bryson, L.K. An Erosion and Sediment Delivery Model for Semi-Arid Catchments. Master's Thesis, Rhodes University, Grahamstown, South Africa, 2015.

37. Foster, I.D.; Rowntree, K.M. Sediment yield changes in the semi-arid Karoo: A palaeoenvironmental recon-struction of sediments accumulating in Cranemere Reservoir, Eastern Cape, South Africa. Z. Für Geomor-Phologie Suppl. Issues 2012, 56, 131-146. [CrossRef]

38. Pitman, W.V. A Mathematical Model for Generating River Flows from Meteorological Data in South Africa; Report no. 2/73; Hydrological Research Unit, University of the Witwatersrand: Johannesburg, South Africa, 1973.

39. Slaughter, A.; Retief, D.; Hughes, D. A method to disaggregate monthly flows to daily using daily rainfall observations: Model design and testing. Hydrol. Sci. J. 2015, 4, 1-15. [CrossRef]

40. Wischmeier, W.H.; Smith, D.D. Predicting Rainfall Erosion Losses: A Guide to Conservation Planning; Government Printing Office: Washington, DC, USA, 1978.

41. Alewell, C.; Borrelli, P.; Meusburger, K.; Panagos, P. Using the USLE: Chances, challenges and limitations of soil erosion modelling. Int. Soil Water Conserv. Res. 2019, 7, 203-225. [CrossRef]

42. Smith, S.J.; Williams, J.R.; Menzel, R.G.; Coleman, G.A. Prediction of Sediment Yield from Southern Plains Grasslands with the Modified Universal Soil Loss Equation. J. Range Manag. 1984, 37, 295. [CrossRef] 
43. Renard, K.; Foster, G.; Weesies, G.; McCool, D.; Yoder, D. Predicting Soil Erosion by Water: A Guide to Conservation Planning with the Revised Universal Soil Loss Equation (RUSLE); Agricultural Handbook No. 703; United States Government Printing: Washington, DC, USA, 1997.

44. Williams, J.R. Sediment-yield prediction with universal equation using runoff energy factor. In Present and Prospective Technology for Predicting Sediment Yield and Sources: Proceedings of the Sediment Yield Workshop Nov 28-30 1972; U.S. Department of Agriculture Sediment Lab: Oxford, MI, USA, 1975; ARS-S-40:244-252.

45. Basson, G. A southern perspective. In Erosion and Sediment Dynamics from Catchment to Coast, 2nd ed.; Di Silvio, G., Basson, G., Eds.; UNESCO Working Series; IHP-VI Technical Document in Hydrology N 82; UNESCO: Paris, France, 2008; SC-2008/WS/34.

46. Sadeghi, S.; Gholami, L.; Darvishan, A.K.; Saeidi, P. A review of the application of the MUSLE model worldwide. Hydrol. Sci. J. 2014, 59, 365-375. [CrossRef]

47. Kinnell, P.I.A. Sediment delivery ratios: A misaligned approach to determining sediment delivery from hillslopes. Hydrol. Process. 2004, 18, 3191-3194. [CrossRef]

48. Gwapedza, D.; Hughes, D.A.; Slaughter, A.R. Spatial scale dependency issues in the application of the mod-ified universal soil loss equation (MUSLE). Hydrol. Sci. J. 2018, 63, 1890-1900. [CrossRef]

49. Moore, I.D.; Burch, G.J. Physical Basis of the Length-slope Factor in the Universal Soil Loss Equation. Soil Sci. Soc. Am. J. 1986, 50, 1294-1298. [CrossRef]

50. Mitchell, J.K.; Bubenzer, G.D. Soil loss estimation. In Soil Erosion; Kirkby, M.J., Morgan, R.P.C., Eds.; John Wiley \& Sons: Chichester, UK, 1980; pp. 17-61.

51. Hughes, D.A.; Hannart, P.; Watkins, D. Continuous baseflow separation from time series of daily and monthly streamflow data. Water SA 2004, 29, 43-48. [CrossRef]

52. Fryirs, K. (Dis)Connectivity in catchment sediment cascades: A fresh look at the sediment delivery problem. Earth Surf. Process. Landf. 2013, 38, 30-46. [CrossRef]

53. de Vente, J.; Poesen, J. Predicting soil erosion and sediment yield at the basin scale: Scale issues and semi-quantitative models. Earth-Sci. Rev. 2005, 71, 95-125. [CrossRef]

54. Grenfell, M.C.; Ellery, W.N.; Grenfell, S.E. Valley morphology and sediment cascades within wetland sys-tems in Kwazulu Natal Drakensberg foothills, eastern South Africa. Cantena 2009, 78, 20-35.

55. Rowntree, K.; Foster, I. A reconstruction of historical changes in sediment sources, sediment transfer and sediment yield in a small, semi-arid Karoo catchment, semi-arid South Africa. Z. Für Geomorphol. Suppl. Issues 2012, 56, 87-100. [CrossRef]

56. Foster, I.D.; Boardman, J.; Gates, J.B. Reconstructing historical sediment yields from the infilling of farm reservoirs, Eastern Cape, South Africa. IAHS Publ. 2008, 325, 440-447.

57. ARC-ISCW. Land Type Map for South Africa from 1972-2006; ARC.: Pretoria, South Africa, 2006.

58. SANBI. Vegetation Map of South Africa; SANBI: Pretoria, South Africa, 2007.

59. Hughes, D.A. Three decades of hydrological modelling research in South Africa. S. Afr. J. Sci. 2004, 100, 638.

60. Hughes, D.A.; Sami, K. Transmission losses to alluvium and associated moisture dynamics in a semiarid ephemeral channel system in Southern Africa. Hydrol. Process. 1992, 6, 45-53. [CrossRef]

61. Sami, K. Recharge mechanisms and geochemical processes in a semi-arid sedimentary basin, Eastern Cape, South Africa. J. Hydrol. 1992, 139, 27-48. [CrossRef]

62. McKenzie, R.S.; Roth, C.; Stoffberg, F. Orange River losses. In Proceedings of the Sixth South African National Hydrological Symposium, Pietermaritzburg, South Africa, 8-10 September 1993; pp. 351-358.

63. Hughes, D.A. Monthly rainfall-runoff models applied to arid and semiarid catchments for water resource estimation purposes. Hydrol. Sci. J. 1995, 40, 751-769. [CrossRef]

64. Cammeraat, L.H. A review of two strongly contrasting geomorphological systems within the context of scale. Earth Surf. Process. Landf. 2002, 27, 1201-1222. [CrossRef]

65. Elwell, H. Modelling soil losses in Southern Africa. J. Agric. Eng. Res. 1978, 23, 117-127. [CrossRef]

66. Le Roux, J.J.; Newby, T.S.; Sumner, P.D. Monitoring soil erosion in South Africa at a regional scale: Review and recommendations: SAEON review. S. Afr. J. Sci. 2007, 103, 329-335.

67. Smith, H.J. Application of Empirical Soil Loss Models in southern Africa: A review. S. Afr. J. Plant Soil 1999, 16, 158-163. [CrossRef]

68. Le Roux, J.; Morgenthal, T.; Malherbe, J.; Pretorius, D.; Sumner, P. Water erosion prediction at a national scale for South Africa. Water SA 2018, 34, 305. [CrossRef]

69. Msadala, V.; Gibson, L.; Le Roux, J.; Rooseboom, A.; Basson, G.R. Sediment Yield Prediction for South Africa: 2010 Edition; South African Water Research Commission: Pretoria, South Africa, 2010.

70. Dlamini, D.; Schulze, R.E. How do Simulated Sediment Yields Vary Spatially and Temporally Under Different Land Uses and States of Degradation or Rehabilitation? A Case Study from the Mbuluzi Catchment in Swaziland. In Modelling as a Tool in Integrated Water Resources Management: Conceptual Issues and Case Study Applications; Schulze, R.E., Ed.; WRC Report 749/1/02; Water Research Commission: Pretoria, South Africa, 2002; Chapter 12; pp. 227-239.

71. Le Roux, J.J. Sediment Yield Potential in South Africa's Only Large River Network without a Dam: Implica-tions for Water Resource Management. Land Degrad. Dev. 2018, 29, 765-775. [CrossRef] 
72. Slaughter, A.; Hughes, D.; Retief, D.; Mantel, S. A management-oriented water quality model for data scarce catchments. Environ. Model. Softw. 2017, 97, 93-111. [CrossRef]

73. Pionke, H.B.; Chesters, G. Pesticide-Sediment Water Interactions. J. Environ. Qual. 1973, 2, 29-45. [CrossRef]

74. Hart, B.T. Uptake of trace metals by sediments and suspended particulates: A review. Hydrobiologia 1982, 91, 299-313. [CrossRef]

75. Kuo, S.; Lotse, E.G. Kinetics of Phosphate Adsorption and Desorption by Lake Sediments. Soil Sci. Soc. Am. J. 1974, 38, 50-54. [CrossRef]

76. Gwapedza, D.; Nyamela, N.; Hughes, D.A.; Slaughter, A.R.; Mantel, S.K.; van der Waal, B. Prediction of sediment yield of the Inxu River catchment (South Africa) using the MUSLE. Int. Soil Water Conserv. Res. 2020, 9, 37-48. [CrossRef]

77. Lexartz-Artza, I.; Wainwright, J. Making connections: Changing sediment sources and sinks in an upland catchment. Earth Surf. Process. Landf. 2011, 36, 1090-1104. [CrossRef]

78. Stirzaker, R.; Biggs, H.; Roux, D.; Cilliers, P. Requisite Simplicities to Help Negotiate Complex Problems. Ambio 2010, 39, 600-607. [CrossRef] 